\title{
Seroprevalence and Associated Risk Factors of Foot and Mouth Disease in Cattle in West Shewa Zone, Ethiopia
}

\author{
Beyan Ahmed, ${ }^{1}$ Lencho Megersa $\left(\mathbb{D},{ }^{2}\right.$ Getachew Mulatu $\mathbb{D}^{2},{ }^{2}$ Mohammed Siraj, ${ }^{2}$ \\ and Gelma Boneya ${ }^{2}$ \\ ${ }^{1}$ Department of Veterinary Science, College of Agriculture and Veterinary Science, Ambo University, P.O. Box 19, Ambo, Ethiopia \\ ${ }^{2}$ Department of Veterinary Laboratory Technology, College of Agriculture and Veterinary Sciences, Ambo University, P.O. Box 19, \\ Ambo, Ethiopia
}

Correspondence should be addressed to Lencho Megersa; lenchomegersa@yahoo.com

Received 7 November 2019; Revised 19 February 2020; Accepted 7 March 2020; Published 31 March 2020

Academic Editor: Annamaria Pratelli

Copyright $(92020$ Beyan Ahmed et al. This is an open access article distributed under the Creative Commons Attribution License, which permits unrestricted use, distribution, and reproduction in any medium, provided the original work is properly cited.

Foot and mouth disease (FMD) is a highly contagious viral disease of cloven-hoofed animals and one of the endemic diseases in Ethiopia. The study was aimed to estimate the seroprevalence and to assess associated risk factors of foot and mouth disease seroprevalence in West Shewa Zone. A total of 384 sera samples were collected from randomly selected cattle and tested using ELISA for antibodies against nonstructural proteins of foot and mouth disease viruses based on IDEXX FMD Multispecies Ab Test (IDEXX Laboratories Inc, USA). The seroprevalence of foot and mouth disease in West Shewa Zone was found to be $40.4 \%$ (95\% CI: 35.46-45.27) at an animal and 74.7\% (95\% CI: 65.58-83.85) at the herd level. Multivariable logistic regression analysis indicated that districts, breed, and animal composition were the potential risk factors of FMD seropositivity. Accordingly, cattle found in Abuna Ginde Beret (odds ratio (OR): 9.1, 95\% CI: 2.4-34.1, $p=0.001$ ), Cheliya (OR: 8.8, 95\% CI: 2.5-31.3, $p=0.001$ ), Bako Tibe (OR: 7.6, 95\% CI: 2.1-28.3, $p=0.002$ ), Tokekutaye (OR: 5.8, 95\% CI: 1.7-19.5, $p=0.004$ ), and Jeldu (OR: 5.3, 95\% CI: $1.3-21.5, p=0.020$ ) districts were more at risk to be infected with FMD than cattle from Ambo. The odds of FMD seropositivity was significantly higher in cattle kept with small ruminants (OR: 2.1, 95\% CI: 1.3-3.3, $p=0.003$ ) than cattle alone. The analysis also revealed that the odds of seropositivity were 6 times higher in crossbred compared with local cattle $(p=0.003)$. The current study found high seroprevalence of FMD in West Shewa Zone. Therefore, cattle should be vaccinated regularly after the identification of specific FMD serotypes circulating in the study area.

\section{Introduction}

Foot and mouth disease (FMD) is a severe highly contagious viral disease caused by an Aphthovirus of the family Picornaviridae. FMD virus has seven serotypes: A, O, C, Asia 1, SAT (Southern African Territories) 1, 2, and 3 [1]. Serotypes reported in Ethiopia are $\mathrm{O}, \mathrm{A}, \mathrm{C}, \mathrm{SAT} 1$, and SAT2 [2]. There is also diversity of strains within each serotype [3]. The disease is characterized by fever, loss of appetite, salivation, and vesicular eruptions in the mouth, on the feet, and teats [1]. FMD primarily affects cloven-hoofed animals including cattle, pigs, sheep, goats, and experimental infections in alpacas and llamas [4]. The morbidity rate of the disease reaches $100 \%$ in cloven-hoofed animals with high mortalities in young animals $[1,5]$. FMD was once distributed worldwide but has been eradicated in some regions, including North America and Western Europe [6].

The occurrence of the disease leads to loss of production, restriction of exports, and other socio-economic problems in the area. The direct impact of FMD includes meat and milk production losses, loss of drought power, lower weight gains, fertility problems, changes in herd structure, delay sale of cattle and products, and death of cattle, while the indirect impacts include additional cost of treatment, vaccination, vaccine delivery, movement control, diagnostic tests, culled cattle, and denied access to both local and international markets [7].

FMD currently is widely prevalent and distributed in all areas of Ethiopia, although the level of the disease prevalence 
may show significant variations across the different farming systems and agroecological zones of the country [8, 9]. Previously, the disease used to frequently occur in the pastoral herds of the marginal low-land areas of the country. However, this trend has changed, and the disease is frequently noted in the central/highland parts of the country $[8,9]$. The seroprevalence investigations undertaken so far in the different parts of the country reported the prevalence that ranges from $5.6 \%$ to $53.6 \%$ in cattle [10-22]. In the current study area, knowing the status of the disease is very important because of a high cattle population and cattle marketing activities, the practice of communal grazing and watering and cattle movement. Although several studies have been conducted on the seroprevalence and associated risk factors of FMD in cattle in different parts of the country, there is a scarcity of information in the study area. Thus, implementing both seroprevalence and associated risk factors investigation is crucial to generate baseline information about the disease. Therefore, the objectives of the present study were to estimate the seroprevalence and to assess associated risk factors of FMD seroprevalence in West Shewa Zone.

\section{Material and Methods}

2.1. Study Area and Animals. The study was conducted in Jeldu, Cheliya, Bako Tibe, Abuna Ginde Beret, Ambo, and Tokekutaye districts of West Shewa Zone, Ethiopia, from December 2017 to September 2019. West Shewa Zone is one of the zones in the centre of the Oromia Regional State, Ethiopia. The zone is divided into 18 districts and 1 urban local administration. West Shewa Zone borders to Southwest Shewa and the Southern Nations, Nationalities and Peoples Region to the south, Jimma to the southwest, East Wollega to the west, Horo Guduru Wollega to the northwest, the Amhara Region to the north, North Shewa to the northeast, and Oromia Special Zone surrounding Addis Ababa to the east.

The altitude of the zone ranges from 1166-3238 meters above sea level (masl), and most areas lie between 2300 and 2630 masl. The topography of the zone is flat which makes the area an ideal place for agriculture. The mean annual temperature and rainfall range from $11-21^{\circ} \mathrm{C}$ and $880-1200 \mathrm{~mm}$, respectively. The crop-livestock mixed farming system is a common practice. This zone is an ideal place for marketoriented commodity development as it is endowed with resources necessary for production and has good access to urban markets such as Addis Ababa, Holeta, and Ambo towns. This zone has a human population of 2,058,676, of which 1,028,501 are males and 1,030,175 are females [23]. Cattle population in the zone was estimated at 2.0 million, while sheep and goat population was 841,001 and 392,473 , respectively [24].

The study animals were cattle that are kept under different management systems (extensive, intensive, and semiintensive farming systems). All local and crossbred cattle of 2 years old and above had a chance to be included in the study.

2.2. Study Design and Sampling Techniques. The cross-sectional study design was employed to assess the seroprevalence of foot and mouth disease and to determine associated risk factors of FMD seroprevalence. Six districts of West Shewa Zone were included in the study based on agroecological conditions. The sample size was calculated based on the following formula [25]:

$$
N=\frac{1.96^{2} P_{\exp }\left(1-P_{\exp }\right)}{d^{2}},
$$

where $N=$ sample size, $P_{\exp }=$ expected prevalence, and $d=$ absolute precision.

$5 \%$ absolute precision and 95\% confidence interval were used to determine the sample size. Accordingly, the minimum sample size calculated was 384 samples.

Six districts were selected by primarily stratifying the districts based on their similarities in agroecological conditions, and then a simple random sampling method was used to select two districts from each stratum. In each district, Kebeles, households, and study animals were selected randomly.

2.3. Sample Collection. The blood was collected from the jugular vein of individual animals using a $10 \mathrm{ml}$ plain vacutainer tubes and then allowed to clot to room temperature overnight. The sera were harvested on a separate tube and labeled. The collected sera were transferred into sterile cryovials and transported in an icebox to the Veterinary Microbiology Laboratory of Ambo University and stored at $-20^{\circ} \mathrm{C}$. Finally, at the end of each sampling, the sera were transported under the cold chain to the National Veterinary Institute (NVI), Bishoftu, and stored at $-20^{\circ} \mathrm{C}[1]$.

\subsection{Serological Diagnosis}

2.4.1. Serological diagnostic tests. The IDEXX FMD Multispecies Ab ELISA Test (IDEXX Laboratories, Inc, USA) was conducted to detect antibodies against nonstructural proteins (NSP) of the FMD virus in serum. IDEXX FMD Multispecies Ab Test provides a rapid, simple, sensitive, and specific method for detecting antibodies against nonstructural proteins (NSP) of the FMD virus in serum bovine origin. This test allows differentiation between samples from infected (presence of antibodies against NSP of FMD virus) and vaccinated (no antibodies against NSP of FMD virus) animals. The test was performed as per the manufacturer's instructions (IDEXX Laboratories Inc). The optical density (OD) reading was recorded using a spectrophotometer at a wavelength of $450 \mathrm{~nm}$ [26].

\subsubsection{Validity Criteria. The test result was validated if}

(i) The mean value of the negative control (NC) is less than or equal to $0.3\left(\mathrm{NC}_{\overline{\mathrm{x}}}^{-} \leq 0.3\right)$

(ii) The mean value of the positive control (PC) is less than or equal to $2\left(\mathrm{PC}^{-} \mathrm{x} \leq 2\right)$

(iii) $\mathrm{PC} \overline{\mathrm{x}}-\mathrm{NC} \overline{\mathrm{x}} \geq 0.3$ 
TABLE 1: Univariable logistic regression analysis of potential risk factors associated with the seropositivity of bovine FMD in West Shewa Zone.

\begin{tabular}{|c|c|c|c|c|c|c|c|}
\hline Risk factors & Categories & $\begin{array}{c}\text { No. of cattle } \\
\text { sampled }\end{array}$ & $\begin{array}{c}\text { No. of } \\
\text { seropositive }\end{array}$ & $\begin{array}{c}\text { Seroprevalence } \\
(\%)\end{array}$ & $\begin{array}{l}\text { Odds } \\
\text { ratio }\end{array}$ & $95 \% \mathrm{CI}$ & $p$ value \\
\hline \multirow{6}{*}{ Districts } & Ambo & 66 & 19 & 28.8 & 1 & - & \\
\hline & Bako Tibe & 78 & 30 & 38.5 & 1.5 & $0.8-3.2$ & 0.223 \\
\hline & Cheliya & 50 & 28 & 56.0 & 3.2 & $1.5-6.8$ & 0.004 \\
\hline & Abuna Ginde Beret & 51 & 24 & 47.1 & 2.2 & $1.0-4.7$ & 0.044 \\
\hline & Jeldu & 43 & 13 & 30.2 & 1.1 & $0-2.5$ & 0.871 \\
\hline & Tokekutaye & 96 & 41 & 42.7 & 1.3 & $0.8-3.7$ & 0.073 \\
\hline \multirow{2}{*}{ Sex } & Male & 175 & 64 & 36.6 & 1 & - & \\
\hline & Female & 209 & 91 & 43.5 & 1.3 & $0.9-2.1$ & 0.166 \\
\hline \multirow{3}{*}{ Breed } & Local & 248 & 89 & 35.9 & 1 & - & \\
\hline & Cross & 136 & 66 & 48.5 & 1.7 & $1.1-2.6$ & 0.016 \\
\hline & Extensive & 316 & 117 & 37.0 & 1 & - & \\
\hline Management & $\begin{array}{l}\text { Semi-intensive and } \\
\text { intensive }\end{array}$ & 68 & 38 & 55.9 & 2.2 & $1.3-3.7$ & 0.005 \\
\hline \multirow{2}{*}{$\begin{array}{l}\text { Sheep and goats in cattle } \\
\text { herd }\end{array}$} & No & 152 & 42 & 27.6 & 1 & - & \\
\hline & Yes & 232 & 113 & 48.7 & 2.4 & $1.6-3.9$ & $\leq 0.001$ \\
\hline \multirow{2}{*}{ Age in years } & $2-4$ & 185 & 72 & 38.9 & 1 & - & \\
\hline & $>4$ & 199 & 83 & 41.7 & 1.1 & $0.8-1.7$ & 0.578 \\
\hline \multirow{2}{*}{ Common grazing } & No & 159 & 59 & 37.1 & 1 & - & \\
\hline & Yes & 225 & 96 & 42.7 & 1.3 & $0.8-1.9$ & 0.274 \\
\hline
\end{tabular}

The multivariable logistic regression model of risk factors analysis indicated that districts, breed, and animal composition in herds had a significant association with seroprevalence of FMD and hence are independent predictors $(p<0.05)$. Abuna Ginde Beret and Cheliya districts have a chance of 9 times more likely to have FMD seropositive when compared to the Ambo district. The prevalence of FMD was higher when cattle keeping with small ruminants, and the data had a statistically significant difference (OR: 2.1) (Table 2).

2.4.3. Interpretation. For each serum sample, the competition percentage was calculated $(\mathrm{S} / \mathrm{P} \%)$ as follows:

$$
\left(\frac{S}{P}\right) \%=100 \times \frac{\text { sample } A(450)-\mathrm{NC} \bar{x}}{\mathrm{PC} \bar{x}-\mathrm{NC} \bar{x}} .
$$

$\mathrm{S} / \mathrm{P} \%$ less than 35 was recorded as negative, and S/P\% greater than or equal to 35 was positive.

2.5. Data Management and Analysis. Raw data were filled and coded in Microsoft Excel. Descriptive statistical analysis and univariable and multivariable logistic regressions were carried out using STATA software version 14.2 [27]. Odds ratio (OR) was calculated for each risk factor for seropositivity to FMD. In all the analyses, confidence levels at $95 \%$ were calculated, and $p<0.05$ was used for the statistical significance level. OR was calculated to determine the degree of association between risk factors and seropositivity to the virus.

\section{Results}

3.1. Seroprevalence. In the present study, a total of 384 cattle of 87 herds were examined for the presence of antibodies against nonstructural proteins (NSP) of FMD virus in their blood sample using IDEXX FMD Multispecies Ab Test. Out of the total sera collected, the seroprevalence of FMD recorded at an animal and herd level was 40.4\% (95\% CI: 35.46-45.27) and 74.7\% (95\% CI: 65.58-83.85), respectively.

3.2. Association with Risk Factors. Table 1 shows the association of risk factors with animal FMD seropositivity.
Accordingly, seropositivity significantly varied $(p<0.05)$ with districts, breed, management, and presence of small ruminants in the cattle herd.

\section{Discussions}

The current seroprevalence of FMD was 40.4\%, which agreed with the seropositivity of $41.5 \%$ found in the eastern part of Tigray [14]. Besides, the seroprevalence of FMD in the present study was in agreement with the finding of Tekleghiorghis [28] who reported 39\% seroprevalence in neighboring Eritrea.

Compared to the current findings, lower seroprevalence was reported from western Ethiopia (9\%), Dire Dawa (8.1\%), southern Ethiopia (9.5\%), South Omo Zone (8.9\%), East Shewa Zone (10.9\%), and Amhara region (14.4\%) $[15,20,29-32]$. On the contrary, higher seroprevalence of FMD was reported by Mekonnen et al. [11], Kibore et al. [33], and Lazarus et al. [34] from Ethiopia, Kenya, and Nigeria with the prevalence of $53.6 \%, 52.5 \%$, and $72.6 \%$, respectively. FMD is endemic in Ethiopia, and its prevalence ranges from $5.6 \%$ to $42.7 \%$ in different parts of the country [8]. Those differences of figures of prevalence reported by different scholars might be due to variation in a management system, free movement of cloven-hoofed animals, unequal distribution of vaccine through the country, intervention and agroclimatic condition, and presence of communal grazing and watering in the current study area.

The $74.7 \%$ seropositivity at the herd level in this study was higher than the reports of Megersa et al. [31] in southern Ethiopia and Hussain et al.'s study [35] in Oman with seroprevalence of $48.1 \%$ and $55.2 \%$, respectively. The higher 
TABLE 2: Results of the multivariable logistic regression model for the predictors of seropositivity of bovine FMD in the West Shewa Zone.

\begin{tabular}{|c|c|c|c|c|}
\hline Risk factors & Categories & Odds ratio & $95 \% \mathrm{CI}$ & $p$ value \\
\hline \multirow{6}{*}{ Districts } & Ambo & 1 & - & \\
\hline & Jeldu & 5.3 & $1.3-21.5$ & 0.020 \\
\hline & Tokekutaye & 5.8 & $1.7-19.5$ & 0.004 \\
\hline & Bako Tibe & 7.6 & $2.1-28.3$ & 0.002 \\
\hline & Cheliya & 8.8 & $2.5-31.3$ & 0.001 \\
\hline & Abuna Ginde Beret & 9.1 & $2.4-34.1$ & 0.001 \\
\hline \multirow{2}{*}{ Breed } & Local & 1 & - & \\
\hline & Cross & 6.30 & $1.9-20.9$ & 0.003 \\
\hline \multirow{2}{*}{ Sheep and goats in cattle herd } & No & 1 & - & \\
\hline & Yes & 2.1 & $1.3-3.3$ & 0.003 \\
\hline \multirow{2}{*}{ Management } & Extensive & 1 & - & \\
\hline & Semi-intensive and intensive & 0.46 & $0.1-1.5$ & 0.197 \\
\hline \multirow{2}{*}{ Sex } & Male & 1 & - & \\
\hline & Female & 1.0 & $0.6-1.6$ & 0.982 \\
\hline
\end{tabular}

prevalence of FMD at the herd level might be due to the common practice of communal grazing and watering in the study area.

The present study showed that there was a statistically significant difference among districts. This is in line with the report of Beyene et al. [32] in western Ethiopia. The prevalence of FMD was higher in Abuna Ginde Beret and Cheliya than in Ambo. This might be due to differences in the unrestricted cattle movement [31]. Abuna Ginde Beret and Cheliya districts practice more communal grazing and watering compared to Ambo.

In the current study, cattle kept with small ruminants had higher odds (2.1 times) of infection than those kept alone $(p<0.5)$. This report corresponds with the studies of Sulayeman et al. [22], Beyene et al. [32], and Gelaye et al. [36]. Earlier studies confirmed that sheep and goats are important reservoirs of FMD virus infection in cattle [36].

In this study, the prevalence of FMD seropositivity was higher in females than males. In similar observation, Mazengia et al. [37], Mesfine et al. [30], and Mekonnen et al. [38] reported that the seroprevalence of bovine FMD was higher in females than males.

In the present study, significantly higher FMD seroprevalence was recorded in crossbred than local cattle. Similarly, higher FMD seroprevalence in crossbred than local cattle was reported by Sulayeman et al. [22] in Ethiopia. The relative higher seroprevalence in crossbred cattle might be attributed to the genetic variation among the breed of animals $[1,9,39]$.

\section{Conclusions}

In conclusion, the findings of the present study revealed that foot and mouth disease is highly prevalent in West Shewa Zone. Statistical analysis indicated that districts, breed, and animal composition in cattle herds are major predictors of the foot and mouth disease occurrence. Identification of specific FMD serotypes circulating in the study area and regular vaccination of cattle are encouraged.

\section{Abbreviations}

FMD: Foot and mouth disease
FMDV: Foot and mouth disease virus

CI: Confidence interval

OR: Odds ratio

CSA: Central statistical agency

NSP: Nonstructural proteins

OD: Optical density

Ab: Antibody

\section{Data Availability}

The data used to support the findings of this study are available from the corresponding author upon request.

\section{Conflicts of Interest}

The authors declare that there are no conflicts of interest regarding the publication of this paper.

\section{Authors' Contributions}

BA, LM, and GM designed the project and analyzed and drafted the manuscript. All authors participated in sample collection, laboratory studies, and critical evaluation of the manuscript. Finally, all authors read and approved the final manuscript.

\section{Acknowledgments}

This study was supported by, Research and community service vice president office. The authors greatly thank cattle owners, animal health workers, and workers of the National Veterinary Institute for their co-operation during this work. This work was supported by Ambo University. The funder had no role in study design, data collection, and analysis, decision to publish, or preparation of the manuscript.

\section{References}

[1] OIE, Foot \& Mouth Disease (FMD), OIE, Paris, France, 2019.

[2] J. L. Martel, "La fièvre aphteuse en Ethiopie. Distribution des sérotypes de virus aphteux," Revue d'élevage et de médecine vétérinaire des pays tropicaux, vol. 27, no. 2, p. 169, 1974. 
[3] S. M. Jamal, G. Ferrari, S. Ahmed, P. Normann, and G. J. Belsham, "Genetic diversity of foot-and-mouth disease virus serotype O in Pakistan and Afghanistan, 1997-2009," Infection, Genetics and Evolution, vol. 11, no. 6, pp. 1229-1238, 2011.

[4] A. H. Andrews, R. W. Blowey, H. Boyd et al., Bovine Medicine: Diseases and Husbandry of Cattle, Blackwell Science Publishing, Hoboken, NJ, USA, 2004.

[5] B. Pattnaik, S. Subramaniam, A. Sanyal et al., "Foot-andmouth disease: global status and future road map for control and prevention in India," Agricultural Research, vol. 1, no. 2, pp. 132-147, 2012.

[6] B. P. Brito, L. L. Rodriguez, J. M. Hammond, J. Pinto, and A. M. Perez, "Review of the global distribution of foot-andmouth disease virus from 2007 to 2014," Transboundary and Emerging Diseases, vol. 64, no. 2, pp. 316-332, 2017.

[7] B. Admassu, K. Getnet, A. Shite et al., "Review on foot and mouth disease: distribution and economic significance," Academic Journal of Animal Diseases, vol. 4, no. 3, pp. 160-169, 2015.

[8] N. Abdela, "Sero-prevalence, risk factors and distribution of foot and mouth disease in Ethiopia," Acta Tropica, vol. 169, pp. 125-132, 2017.

[9] A. K. Wubshet, J. Dai, Q. Li, and J. Zhang, "Review on outbreak dynamics, the endemic serotypes, and diversified topotypic profiles of foot and mouth disease virus isolates in Ethiopia from 2008 to 2018," Viruses, vol. 11, no. 11, p. 1076, 2019.

[10] B. Bayissa, G. Ayelet, M. Kyule, Y. Jibril, and E. Gelaye, "Study on seroprevalence, risk factors, and economic impact of footand-mouth disease in Borena pastoral and agro-pastoral system, southern Ethiopia," Tropical Animal Health and Production, vol. 43, no. 4, pp. 759-766, 2011.

[11] H. Mekonnen, S. Workineh, M. Bayleyegn et al., "Antimicrobial susceptibility profiles of mastitis isolates from cows in three major Ethiopian dairies," Revue de médecine vétérinaire, vol. 156, no. 7, p. 391, 2005.

[12] T. S. Jenbere, M. Etana, and H. Negussie, "Study on the risk factors of Foot and Mouth Disease in selected districts of Afar pastoral area, northeast Ethiopia," Journal of Animal and Veterinary Advances, vol. 10, no. 11, pp. 1368-1372, 2011.

[13] A. Mohamoud, E. Tessema, and H. Degefu, "Seroprevalence of bovine foot and mouth disease (FMD) in awbere and babille districts of jijiga zone, Somalia regional state, eastern Ethiopia," African Journal of Microbiology Research, vol. 5, no. 21, pp. 3559-3563, 2011.

[14] G. Ayelet, E. Gelaye, H. Negussie, and K. Asmare, "Study on the epidemiology of foot and mouth disease in Ethiopia," Revue Scientifique et Technique de l'OIE, vol. 31, no. 3, pp. 789-798, 2012.

[15] F. Abunna, S. Fikru, and T. Rufael, "Sero-prevalence of footand-mouth disease (FMD) at Dire Dawa and its surroundings, eastern Ethiopia," Global Veterinaria, vol. 11, no. 5, pp. 575-578, 2013.

[16] F. Desissa, K. Makita, A. Teklu et al., "Contamination of informally marketed bovine milk with Staphylococcus aureus in urban and peri urban areas of Debre-Zeit, Ethiopia," African Journal of Microbiology Research, vol. 6, no. 29, pp. 5852-5856, 2012.

[17] G. Zerabruk, G. Romha, and T. Rufael, "Sero-epidemiological investigation of foot and mouth disease in cattle managed under extensive husbandry system in Tigray, northern Ethiopia," Global Veterinary, vol. 13, pp. 112-116, 2014.

[18] D. Misgana, J. Yasmin, I. Ahmed et al., "Sero-prevalence of foot and mouth disease of cattle in Bale Zone, Oromiya regional state, Ethiopia," Global Veterinaria, vol. 11, no. 1, pp. 59-64, 2013.

[19] G. Alemayehu, G. Zewde, and B. Admassu, "Seroprevalence of foot and mouth disease (FMD) and associated economic impact on Central Ethiopian cattle feedlots," Journal of Veterinary Medicine and Animal Health, vol. 6, no. 5, pp. 154-158, 2014.

[20] D. Belina, B. Girma, and S. Mengistu, "Sero-prevalence of bovine foot and mouth disease in selected districts of eastern showa zone, Oromia regional state, Ethiopia," Global Journal of Science Frontier Research, vol. 16, no. 4, 2016.

[21] A. Tesfaye, M. Sehale, A. Abebe, A. Muluneh, and D. Gizaw, "Sero-prevalence of foot and mouth disease in cattle in Borena Zone, Oromia regional state, Ethiopia," Ethiopian Veterinary Journal, vol. 20, no. 1, pp. 55-66, 2016.

[22] M. Sulayeman, F. Dawo, B. Mammo, D. Gizaw, and D. Shegu, "Isolation, molecular characterization and sero-prevalence study of foot-and-mouth disease virus circulating in central Ethiopia," BMC Veterinary Research, vol. 14, no. 1, p. 110, 2018.

[23] CSA, Population and Housing Census of Ethiopia, CSA, Easton, PA, USA, 2007.

[24] CSA, Agricultural Sample Survey, Vol. 38, CSA, Easton, PA, USA, 2013.

[25] M. Thrusfield, Veterinary Epidemiology; Describing Disease Occurrence, Blackwell Publishing, Hoboken, NJ, USA, 2007.

[26] Foot and Mouth Disease (FMD), Multispecies Antibody TestIDEXX US, Westbrook, ME, USA, 2019.

[27] StataCorp LP, Stata/SE 14.2 (statistical software), Vol. 2, StataCorp LP, College Station, TX, USA, 2018.

[28] T. Tekleghiorghis, K. Weerdmeester, F. van Hemert-Kluitenberg et al., "Foot-and-Mouth Disease Seroprevalence in Cattle in Eritrea," Transboundary and Emerging Diseases, vol. 64, no. 3, pp. 754-763, 2017.

[29] B. Molla, G. Ayelet, Y. Asfaw, Y. Jibril, G. Ganga, and E. Gelaye, "Epidemiological study on foot-and-mouth disease in cattle: seroprevalence and risk factor assessment in South Omo zone, south-western Ethiopia," Transboundary and Emerging Diseases, vol. 57, no. 5, pp. 340-347, 2010.

[30] M. Mesfine, S. Nigatu, N. Belayneh, and W. T. Jemberu, "SeroEpidemiology of foot and mouth disease in domestic ruminants in Amhara region, Ethiopia," Frontiers in Veterinary Science, vol. 6, p. 130, 2019.

[31] B. Megersa, B. Beyene, F. Abunna, A. Regassa, K. Amenu, and T. Rufael, "Risk factors for foot and mouth disease seroprevalence in indigenous cattle in Southern Ethiopia: the effect of production system," Tropical Animal Health and Production, vol. 41, no. 6, pp. 891-898, 2009.

[32] B. Beyene, T. Tolosa, T. Rufael, B. Hailu, and T. Teklue, "Foot and mouth disease in selected districts of western Ethiopia: seroprevalence and associated risk factors," Revue Scientifique et Technique de l'OIE, vol. 34, no. 3, pp. 939-952, 2015.

[33] B. Kibore, C. Gitao, A. Sangula et al., "Foot and mouth disease sero-prevalence in cattle in Kenya," Journal of Veterinary Medicine and Animal Health, vol. 5, no. 9, pp. 262-268, 2013.

[34] D. D. Lazarus, W. Schielen, Y. Wungak et al., Sero-epidemiology of Foot-And-Mouth Disease in Some Border States of Nigeria, 2012.

[35] M. H. Hussain, M. H. H. Body, A. H. A. Al-Subhi et al., "Seroepidemiology of foot and mouth disease (FMD) virus non-structural protein (NSP) antibodies in the livestock of Oman," Acta Tropica, vol. 199, p. 105106, 2019.

[36] E. Gelaye, G. Ayelet, T. Abera et al., "Seroprevalence of foot and mouth disease in Bench Maji zone, Southwestern 
Ethiopia," Journal of Veterinary Medicine and Animal Health, vol. 1, no. 1, pp. 005-010, 2009.

[37] H. Mazengia, M. Taye, H. Negussie, S. Alemu, and A. Tassew, "Incidence of foot and mouth disease and its effect on milk yield in dairy cattle at Andassa dairy farm, Northwest Ethiopia," Agriculture and Biology Journal of North America, vol. 1, no. 5, pp. 969-973, 2010.

[38] H. Mekonen, D. Beyene, T. Rufael, and A. Abunna, "Study on the prevalence of foot and mouth disease in borana and guji zones, southern Ethiopia," Veterinary World, vol. 4, no. 7, p. 293, 2011.

[39] M. Sahle, R. M. Dwarka, E. H. Venter, and W. Vosloo, "Comparison of SAT-1 foot-and-mouth disease virus isolates obtained from East Africa between 1971 and 2000 with viruses from the rest of sub-Saharan Africa," Archives of Virology, vol. 152, no. 4, pp. 797-804, 2007. 